\title{
Performance of garden pea varieties for their growth and yield characteristics in Vidharbha region of Maharashtra, India
}

\author{
Pushpendra Khichi ${ }^{1}$, Rajani Pant ${ }^{2}$ and Sandeep Upadhayay ${ }^{3^{*}}$ \\ ${ }^{1}$ Department of Horticulture, Dr. PDKV, Akola- 444104 (Maharashtra), INDIA \\ ${ }^{2}$ Department of Horticulture, Govind Ballabh Pant University of Agriculture and Technology Pantnagar, District \\ Udham Singh Nagar- 263145 (Uttarakhand), INDIA \\ ${ }^{3}$ Natural Resource Management Department, Veer Chandra Singh Garhwali College of Horticulture (Uttarakhand \\ University of Horticulture and Forestry) Bharsar, District Pauri- Garhwal- 246123 (Uttarakhand), INDIA \\ *Corresponding author. E-mail: mistersandeep@gmail.com \\ Received: November 2, 2016; Revised received: April 24, 2017; Accepted: October 22, 2017
}

\begin{abstract}
An experiment was conducted in 2013 to study the performance of different varieties of garden pea under Akola condition at Department of Horticulture Dr.Punjabrao Deshmukh Krishi Vidhyapeeth, Akola, Maharashtra. Eight varieties were evaluated on black soil in replicated randomized block design and Results were found significant for all characters among these varieties. All varieties exhibited considerable variation in their performance for most of the parameters. Better growth and yield parameters in terms of plant height $(\mathrm{cm})$, number of branches/plant, days to first flowering, number of green pod/plant, green pod weight, green pod length, pod yield/plant, green pod yield per plot and green pod yield per ha were noticed in all varieties. Maximum plant height was observed in Jawahar Matar-2 $(72.26 \mathrm{~cm})$ and minimum was in Palam Priya $(28.46 \mathrm{~cm})$. In case of number of pods plant ${ }^{-1}$ was maximum in PB-89 (16.43) followed by Palam Triloki (13.9) and minimum in Jawahar Matar-2 (9.83). Similarly for pod characters, average pod weight, maximum pod weight was recorded in PB-89 (6.12 g) and minimum was recorded in Arka Kartik (3.27g). Green pod yield/plant was highest in PB-89 (87.93 g), Palam Triloki (75.45 g) and Ankur (68.42 g). Whereas, maximum green pod/yield. was recorded in PB-89 (93.12q/ha) followed by Palam Triloki (76.97q/ha). Among all these varieties highest protein and Total Soluble Solid contents was recorded in Palam Triloki variety $(23.06 \%$ and $17.67 \%$ respectively). PB-89, Palam Triloki and Ankur had the highest yields over the others, hence, they are recommended to farmers in semi-arid condition of Vidharba region for cultivation.
\end{abstract}

Keywords: Garden pea, Quality, Varieties, Yield

\section{INTRODUCTION}

Pea (Pisum sativum L.), a leguminous crop, belongs to family Leguminoseae, and contains higher amount of protein having essential amino acids particularly lysine (Nawab et al, 2008). Peas are very common nutritious vegetable and are mainly cultivated as winter crop throughout the world. This crop is very much valuable in crop rotation. It is considered as an important cultivated legume next to soya bean, groundnut and beans. The genus Pisum was considered to be consisted of five species: $P$. fulvum, $P$. abyssinicum, $P$. sativum L., $P$. humile and P. elatius mostly found in Mediterranean area and West Asia, out of which only P. sativum is cultivated (Verhinin et al., 2003). P. sativum having a chromosome number $2 \mathrm{n}=14$, plant is short lived, herbaceous annual which climbs by leaflets tendrils.

Pea cultivation is widespread in areas having a mild and warm climate, because relatively high or low temperatures are the most important factors limiting pea cultivation (Ambrose, 2008). A dry climate is also unsuitable for the plant, particularly during flowering and pod development. Cumulative mean temperature requirements for floral initiation varied and this data could be used to decide sowing dates for different cultivars (Roques et al., 1992). Dry periods substantially decrease yields (Ozdemir, 2002). Yield can be increased by early sowing and the use of the seeds of early flowering and maturing cultivars in production (Dumolin et al., 1996).

India ranked second in the world for production of vegetables next to China. In India, Pea is cultivated on an area of 459 thousand hectares with a total production of4329 thousand tons and productivity $9.4 \mathrm{t} / \mathrm{ha}$ (Anonymous, 2014 ). Pea is very rich in protein (7.2 g), vitamin A (139 I.U.) and C (9 mg), calcium (20 $\mathrm{mg}$ ), phosphorus (139 mg), energy (81 kcal), carbohydrates $(14.5 \mathrm{~g})$, sugars $(5.67 \mathrm{~g} / 100 \mathrm{~g})$ of edible portion (Peter et al, 2012). Large proportion of garden pea is processes (cannel, frozen or dehydrated) for consumption in the off season. It is used as a soil building crop as a chemical fertilizer is becoming less available and more expensive. Water requirement of pea is less i.e. about $300 \mathrm{~mm}$ (Makasheva, 1983). 
The present study was therefore, mainly envisaged to evaluate the suitable variety with high yielding and early maturing capacity in Vidhrabha region in Maharastra.

\section{MATERIALS AND METHODS}

The experiment was conducted to identify potential varieties suitable for growing under semi-arid conditions of Vidharba region in Maharashtra. Akola is situated between $22.2^{\circ} \mathrm{N}$ latitude and $72.02^{\circ} \mathrm{E}$ longitudes. The altitude of place is $307.2 \mathrm{~m}$ above mean sea level. The experiment was initiated during winter (rabi) season in 2013-14 at Main Garden, Department of Horticulture, Dr. PDKV, Akola. The experimental plots were laid out in a replicated randomized block design (RBD). Eight varieties of pea viz., Palam Priya, Palam Smool, Palam Triloki, PB-89, Jawahar Matar-2, Ankur, Arkel, and Arka Kartik were grown in the experimental plot. The crop was planted on November 20, 2013 on well-prepared beds. Seeds were sown on flat beds measuring $3.15 \mathrm{~m} \mathrm{x} 1.20 \mathrm{~m}$ row to row and plant to plant distance was maintained at $35 \mathrm{~cm} \mathrm{x} 15$ $\mathrm{cm}$. First irrigation was applied just after the sowing of seed taking care to avoid over flooding. Subsequent irrigations were applied at an interval of 7 - 15 days according to the need of the crop. The crop was fertilized normally and hoed twice manually to keep it free from weeds. The observations were recorded on five competitive plants for pod yield and other qualitative characters viz., days to first flowering, number of green pod plant ${ }^{-1}$, green pod weight, green pod length, protein content on dry basis and total soluble solid (TSS) contents. Data were analysis statistically as per method suggested by Panse and Sukhatme, (1957).

\section{RESULTS AND DISCUSSION}

\section{Growth parameters}

Number days to germination: The data revealed highly significant differences among garden pea cultivars for this trait. Minimum number of days required for germination was recorded in Palam Triloki (4.66), followed by Palam Priya (6.33) and Palam Triloki (6.33) whereas, maximum days required for germina- tion of garden pea seed was in Arka Kartik (9.33). The presence of light advances the metabolic changes that take place during the different stages of germination. The variations in germination among the varieties might be attribute to a climatic factor viz., temperature, rainfall and relative humidity which can enhance seed germination, (Kumaran et al., 1995).

Plant height: Relevant data indicated significant differences among the cultivars. Comparison of cultivar means reveals that the maximum plant height $(72.26$ $\mathrm{cm})$ was attained by the plants of Jawahar Matar-2 followed by Arka Kartik $(56.73 \mathrm{~cm})$, while the minimum was recorded in Palam Priya $(28.46 \mathrm{~cm})$ Table 1. During vegetative growth, pea stems develop 20 to 25 nodes, which in turn determine the height of plants. The number of nodes is primarily dependent on the cultivar used (Muehlbauer and McPhee., 1997). As the height of the plants varied among the cultivars, therefore, it may be stated that the height is a genetic character. In an earlier study, Gentry (1971) also reported differences in plant height among different pea cultivars.

Number of branches per plant: The data presented in Table 1 revealed significant variation in different garden pea varieties. Significantly the maximum (20.33) number of branches was noted in the variety Arka Kartik, which was found at par with the varieties PB-89. The remaining cultivars Arkel, Ankur and Palam Triloki were at par with each other whereas, the minimum (14.06) number of branches/plant were recorded in variety Palam Smool. It was observed that some genotypes had determinate type growth and their plant bloomed and exhausted simultaneously; hence, these had less branches/plant. In germplasm collected from different climatic conditions, rate of acclimatization may be considered the possible cause of variation (Hatam and Amanullah. 2001). Moreover, this variation could be due to genetic variability of different germplasms. Similar results were elucidated by Kakar et al. (2002).

Internodal length: The statistical analysis indicated significant differences among peas genotypes regarding intermodal length which might between 4.13 to $9.90 \mathrm{~cm}$. The maximum length of internodes was rec-

Table1. Mean performance of various Varieties of Gardenpea with respect to different horticultural traits.

\begin{tabular}{lccccc}
\hline Varieties & $\begin{array}{c}\text { No. of days to } \\
\text { germination }\end{array}$ & $\begin{array}{c}\text { Plant height } \\
(\mathbf{c m})\end{array}$ & $\begin{array}{c}\text { No. of branches/ } \\
\text { plant }\end{array}$ & $\begin{array}{c}\text { Inter-nodal } \\
\text { length }(\mathbf{c m})\end{array}$ & $\begin{array}{c}\text { No. of days to 1 } \\
\text { flowering }\end{array}$ \\
\hline Palam Priya & 6.33 & 28.46 & 15.93 & 4.13 & 47.40 \\
Palam Smool & 6.33 & 33.80 & 14.06 & 4.66 & 44.06 \\
Palam Triloki & 4.66 & 44.46 & 17.80 & 5.56 & 32.06 \\
PB-89 & 7.66 & 42.06 & 19.20 & 5.06 & 40.00 \\
Jawahar Matar-2 & 7.66 & 72.26 & 15.40 & 9.90 & 40.66 \\
Ankur & 8.33 & 52.73 & 17.23 & 6.80 & 40.20 \\
Arkel & 8.00 & 44.33 & 17.33 & 4.56 & 41.56 \\
Arka Kartik & 9.33 & 56.73 & 20.33 & 9.23 & 53.86 \\
SE(m) \pm & 0.48 & 3.35 & 0.43 & 0.26 & 0.33 \\
C. D. & 1.47 & 10.11 & 1.30 & 0.79 & 1.01 \\
(P $>0.05)$ & & & & & \\
\hline
\end{tabular}


Pushpendra Khichi et al. / J. Appl. \& Nat. Sci. 9 (4): 2300 - 2304 (2017)

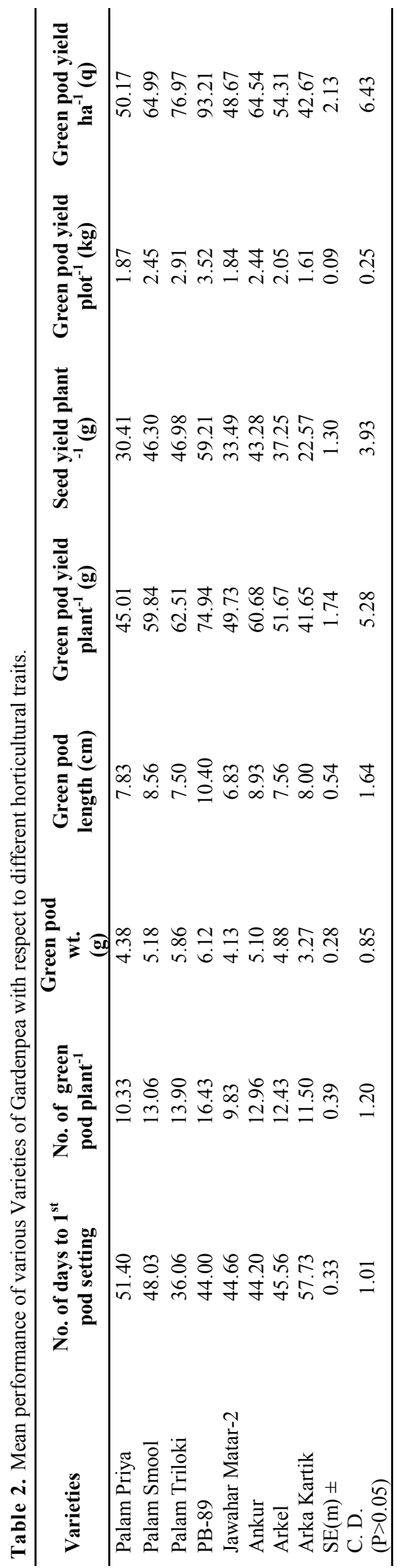

orded under Jawahar Matar-2 followed by Arka Kartik and Ankur with $9.23 \mathrm{~cm}$ and $6.80 \mathrm{~cm}$, respectively, whereas the minimum length of internodes was recorded under Palam Priya The increase in length of internode might be due to the enhanced cell division which increased the number of vegetative buds on the main stem (Armstrong and Pate, 1994). The temperature and moisture conditions also favoured the vegetative development of the crop by Davies et al., (1985), Biederbeck and Boudman, (1994).

Number of days to first flowering: The time taken from germination to flower initiation revealed significant differences among the cultivars. It is evident from Table 1 that Arka Kartik took the maximum days (53.86) to first flowering followed by Palam Priya (47.4 days), whereas Palam Triloki took the minimum number of days to start flowering (32.06). The cultivars taking minimum number of days to flowering are comparatively early maturing than other cultivars (Ozdemir, 2002).

\section{Yield parameters}

Number of days to first pod setting: Differences among the pea cultivars in terms of first pod setting were significant $(\mathrm{p}>0.05)$ which was found between 36.07 to 57.73 days. The minimum days taken to first pod setting was observed under the treatment Palam Triloki, followed by PB-89, Jawahar Matar-2 and Ankur. Whereas, the maximum days taken to first pod setting was observed under the treatment Arka Kartik. The possible reason of early flowering and pod setting in certain varieties indicated adaptability of these varieties in a particular environment, better and efficient utilization of nutrients in a relatively hostile environment which might have resulted in early termination of vegetative phase and initiation of reproductive stage as compared to varieties which took longer time to flowering and pod setting (Ishtiaq et al., 1996). Similar results have also been reported earlier in Gardenpea by Hussain et al., 2002, Singh et al., 2004 and Javaid et al., 2002.

Number of green pods per plant: Data concerning number of pods/plant indicated significant difference among the cultivars. However, all the cultivars except PB-89 (16.43) produced nearly the same number of pods/plant. The cultivar Palam Priya (10.33) and Jawahar Matar-2 (9.83) produced minimum number of green pods/plant Table 2. It indicated that priority could be given to a certain cultivar over others on the basis of number of pods/plant, if other parameters were also at optimum level. More number of pods/plant may be due to small pod size as less nutrient are required for small pods compared with larger pods (Javaid et al, 2002). Pods/plant have significant and positive correlation with biological yield, grain yield and harvest index. Similar results have also been reported by Hussain et al., (2005) in garden pea cultivars.

Green pod weight: The data showed that the cultivars 
Table 3. Mean performance of various varieties of Gardenpea with respect to different horticultural traits.

\begin{tabular}{lcc}
\hline Varieties & Protein content (\%) & TSS content (\%) \\
\hline Palam Priya & 21.74 & 17.34 \\
Palam Smool & 22.39 & 16.87 \\
Palam Triloki & 23.06 & 17.67 \\
PB-89 & 22.40 & 17.18 \\
Jawahar Matar-2 & 16.32 & 15.07 \\
Ankur & 20.27 & 16.75 \\
Arkel & 19.28 & 17.00 \\
Arka Kartik & 21.08 & 15.21 \\
SE $(\mathrm{m}) \pm$ & 0.45 & 0.12 \\
C.D. $(\mathrm{P}>0.05)$ & 1.38 & 0.36 \\
\hline
\end{tabular}

had significant difference among their means for green pod weight. The cultivar PB-89 had the maximum green pod weight $(6.12 \mathrm{~g})$. The cultivars Palam Smool and Ankur tended to stand at par with Palam Triloki. The poorest performance was shown by the cultivars Arka Kartik and Jawahar matar-2 having only $3.27 \mathrm{~g}$ and $4.13 \mathrm{~g}$ of green pod weight respectively Table 2 . This variation might be due to the inherent potential of cultivars and their interaction with soil and climatic conditions. Agrawal et al., (2006) have reported similar results in gardenpea. In general, pod size is a varietal character, but it is also affected by vigour of plant (Bozoglu et al., 2007). Greater availability of nutrients especially during pod formation and development stages of more vigorous pea varieties might have translocated maximum of its reserved food material towards pod formation and development (Habib and Jamin, 2003).

Green pod length: Data on pod length showed significant differences among the cultivars. A comparison of means for cultivars indicated that PB- 89 exhibited the maximum pod length $(10.4 \mathrm{~cm})$ followed by Ankur $(8.93 \mathrm{~cm})$ and statistically it remained at par with $\mathrm{PB}$ 89. The minimum pod length $(6.83 \mathrm{~cm})$ was recorded in Jawahar Matar-2 Table 2. A number of earlier workers have already reported that pea cultivars vary greatly in size and shape of pods and number of seeds pod (Gentry 1971, Muehlbauer 1997, and Kakar et al, 2002)

Green pod yield: It is clear from the data that the cultivars had significant differences for the parameter under study. Maximum green pod weight per plant was obtained from the cultivars PB-89 (74.94 g), Palam Triloki (62.51 g) and Ankur (60.68 g). All other cultivars behaved statistically alike. Minimum green pod yield/plant was obtained from the cultivars Arka Kartik (41.65 g) and Palam Priya (45.01 g). Both these cultivars also stood at par with each other Table 2. Since green pod yield ha was calculated on the basis of yield per plant and number of plants/ha, therefore, it followed the same pattern of significance as the green pod yield per plant. Yield is a complex character determined by the interaction of many heritable characters with soil, climate and agronomic conditions (Makasheva, 1983). Maximum yield requires maxi- mum vegetative growth during crop establishment (Muehlbauer and McPhee, 1997). In the present study, the cultivars PB-89 and Palam Triloki had more number of primary branches/plant and thus, resulted in higher yields. It is however; strange that Arka Kartik with more number of primary branches/plant resulted in lower yield, which might be due to the climatic and soil condition of the cultivar.

Seed yield plant: Relevant data indicated that significant differences existed among the cultivars. Comparison of cultivar means revealed that the cultivar PB-89 produced the maximum seed yield/plant (59.21 g) followed by Palam Triloki, Ankur and Palam Smool whereas the cultivar Arka Kartik produced the lowest seed yield/plant $(22.57 \mathrm{~g})$. This also stood at par with Palam Priya, Jawahar Matar-2 and Arkel Table 2. These results showed that the cultivar Arka Kartik is a poor variety to produce adequate seed yield/plant. The results suggest a strong relationship between source and sink and maximum translocation of food material from vegetative to reproductive portion in good environmental condition which cause higher seed weight (Ali et al, 2002). The rate of acclimatization of genotypes may be considered the possible cause of this variation. Moreover, this variation might be due to genetic variability of different genotypes (Hatam and Amanullah, 2001).

Quality parameters: Pertinent data indicated significant differences in this respect among the cultivars. A comparison of cultivar means showed that Palam Triloki exhibited the highest protein content of $23.06 \%$. The minimum protein content was recorded in Jawahar Matar-2 (16.32\%) followed by Arkel (19.28\%). The highest TSS content was found in Palam Triloki cultivar $(17.67 \%)$ and minimum was in Jawahar Matar-2 (15.07\%). Other varieties have TSS content at par with Palam Triloki. These cultivars also behaved statistically alike (Table 3 ).

\section{Conclusion}

This study evaluated the performance of eight varieties of garden pea in semi-arid condition of Vidharba region in terms of plant height $(28.46-72.26 \mathrm{~cm})$, number of branches/plant (14.06-20.33), days to first flowering (32.06-53.86), number of green pod/plant (9.83-13.90), green pod weight (3.27-6.12 g), green pod length (6.83 $-10.40 \mathrm{~cm})$, green pod yield/plant (41.65-74.94 gm), green pod yield/plot (1.61-3.52 kg), seed yield/plant (22.57-59.21 gm), green pod yield/ha (42.67-93.21 q), protein content $(16.32-23.06 \%)$ and TSS content (15.07-17.67). The results show that, PB-89, Palam Triloki and Ankur differed significantly $(\mathrm{P}<0.05)$ in their performance when compared to the other varieties especially Jawahar Matar-2 and Arka Kartik that had the lowest values for all parameters assessed. PB-89, Palam Triloki and Ankur had the highest yields over the others, hence they are recommended to farmers in 
semi-arid condition of Vidharba region for cultivation.

\section{REFERENCES}

Agrawal A., Gupta S. and Ahmed Z. (2006). Performance of garden pea (Pisum sativum) cultivars in highaltitude cold desert of Ladakh. Indian Journal of Agriculture 76 (12):713-715.

Ali I., Rub A. and Hussain S. A. (2002). Screening of pea germplasm for growth, yield and resistance against powdery mildew under the agro-climatic conditions of Peshawar. Sarhad Journal of Agriculture 18(2): 177-181.

Ambrose, L. (2008). Pea breeding: a review. J. Hortic. 61:407.

Anonymous (2013). Database area, production, productivity of major in India. Available from www.nhb.gov.in

Armstrong, E.L. and Pate, J.S. (1994). Patterns of growth, biomass production and photo-synthetic performance in genotypes of contrasting morphology in field pea. Aust. J. Agri. Res., 45 (4): 1347-1362.

Biederbeck, V.O. and Boudman, O.T. (1994). Water use by annual green manure legumes in dryland cropping system. Agro. J., 8 (6): 543-549.

Bozoglu, H, Peksen, E., Peksen, A. and Gulumser. A. (2007). Determination of the yield performance and harvesting periods of fifteen pea (Pisum sativum L.) cultivars sown in autumn and spring. Pakistan J. Bot. 39 (6): 2017-2025.

Davies, D. R, Berry G.J., Health M.C. and Dawkins, T.C.K. (1985). Pea (Pisum sativum L.) In Grain legume crops. Collins, London. 147-198.

Dumolin, V.B., Denis, J.B., Henaut I.L. and Eteve, G. (1996). Interpreting Yield Instability in Pea Using Genotypic and Environmental Covariates. Crop Science. 36: 1154.

Gentry, H.S. (1971). Pisum Resources: A preliminary survey. Plant Genetic Resources Newsletter, 25: 3-13.

Habib, N. and Zamin, M. (2003). Off-season pea cultivation in Dir Kohistan valley. Asian Journal of Plant Science. 2(3): 283-285.

Hatam, M. and Amanullah, (2001). Grain yield potential of garden peas (Pisum sativum L.) germlpasm. J. Biol. Sci. 1 (4): 242-244.

Hussain, S.A. and Badshah, N. (2002). Study on the adaptive behaviour of exotic pea (Pisum sativum L.) varieties under local condition of Peshawar. Asian Journal of Plant Science. 1(5): 567-569.

Hussain, S.A., Hussain, M., Qasim, M. and Hussain, B.
(2005). Performance and economic evaluation of pea varieties at two altitudes in Kaghan Valley. Sarhad $J$. Agric. 21 (4) : 587-589.

Ishtiaq, M., Ahmad, Z. and Shah, A. (1996). Evaluation of exotic cultivars of pea in Peshawar valley. Sarhad $J$. Agric. 12 (4) : 425-431.

Javaid, A.G., and Anwar, R. (2002). Evaluation of local and exotic pea (Pisum sativum) germplasm for vegetative and dry grain traits. Pak. J. Bot. 34 (4) : 419-427.

Kakar, A.A., Saleem, M., Shah, R. and Shah, S.A.Q. (2002). Growth and marketable green pod yield performance of pea (Pisum sativum L.) under varying levels of NPK fertilizers. Asian J. Plant Sci. (5) : 532-534.

Kumaran, N. and Thamburaj, S. (1995). Genetic variability in pea (Pisum sativum L.). J. South Indian Hort., 43 (1\&21) : 10-13.

Makasheva, R.Kh.(1983). The Pea. Oxonian Press Pvt. Ltd., New Delhi, India, pp. 78-107.

Muehlbauer, E.J. and McPhee, K E (1997). Peas. In The Physiology of Vegetable Crops (Ed. H C Wein). CAB International, Wallingford, UK. pp. 429-459.

Nawab, N.N., Subhani, G.M., Mahmood, K., Shakil, Q. and Saeed, A. (2008). Genetic variability, correlation and path analysis studies in garden pea (Pisum sativum L.). J. Agric. Res. 46 (4): 333-340.

Ozdemir, S. (2002). Yemeklik Baklagiller. Hasad Yayıncılık Ltd. Sti., 142.

Panse, V.G. and P.V. Sukhatme (1967). Statistical method of Agricultural workers, New Delhi, ICAR Publication, pp. 123-159.

Peter, K.V. and Pranab, Hazara (2012). Hand Book of Vegetables. Stadium press LLC. pp-481.

Roques, F.P., Duchene, E. and Scaife, A. (1992). Variation of the length of the vegetative period in Pisum sativum (L.) consequences on the choices of sowing date. Proceedings second congress of the European society for agronomy, Warwick University, 126-127 (CAB Abstract 88 of 96/1992).

Singh, M.K., Srivastava, C.P. and Agrawal, N. (2004). Comparative performance of field pea genotypes against pea leaf miner, Chromatomyia horticola (Goureau) and pea pod borer, Etiella zinckenella (Treitschke). J. Ent. Res. 28 (4): 345-349.

Verhinin, T., Noma, J., Nisnitarumozu, J. (2003). Seed productivity and germiability of various gardenpea genotypes collected in Medditerrian region. Memoirs of the Faculty of Agric. Magushima Univ. 34:12. 